\title{
The effect of partner digitalization expertise on audit fees
}

\section{By: Arpine Maghakyan, Henry Jarva, Lasse Niemi and Jukka Sihvonen}

\begin{abstract}
We document a fee premium for audit partners who have gained expertise in digitalization by specializing in highly or similarly digitalized clients. Overall, our evidence is consistent with the view that the digitalization of a client's business and information systems provides audit partners an opportunity to differentiate themselves as experts in digitalization and earn a fee premium. In our sample of listed and private firms in Finland, we find a fee premium of 1335\%. For U.S.-listed companies, we document a fee premium of 63-65\%. This study contributes to archival research on auditor expertise and audit pricing by showing that expertise in digitalization is separate from industry-specific and generic knowledge accumulated by years in the profession, enhancing our understanding of the nature of auditing in the current audit environment.
\end{abstract}

Keywords: audit partner expertise, auditor specialization, audit fees, digitalization, business automation.

JEL classification: L84, M40, M42 


\section{Introduction}

The overall objective of this study is to examine whether an audit partner's expertise from auditing highly digitalized ${ }^{1}$ clients results in an audit fee premium. For professional services such as auditing, the expertise of individuals plays a crucial role in delivering value to the client. Expertise, however, comes in many forms. Bonner and Lewis (1990) find that the expertise of an auditor emerges from three types of knowledge: (1) general knowledge in business, (2) knowledge of the rules and principles of accounting and auditing, and (3) a narrower subspecialty knowledge. The subspecialty knowledge is obtained through auditing clients that are sufficiently similar to each other (Zerni 2012).

Prior research shows that auditors with several clients in the same industry perform better and earn higher fees compared to their non-industry specialist counterparts (Chi and Chin 2011; Goodwin and Wu 2016; Zerni 2012). The fee premium exists because similarities among the clients in the same industry allow auditors to accumulate industry-specific subspecialty knowledge through repetition. However, it is noteworthy that subspecialty knowledge arising from repetition is not necessarily limited to industry-specific knowledge; rather, it may relate to any client characteristic that needs to be considered in the audit process. For example, Zerni (2012) provides evidence that individual auditors could specialize in different market segments in terms of client size or ownership type (i.e., whether the client is a listed or privately held company).

We argue that the digitalization of the client's business and information processes provides auditors with an opportunity to differentiate themselves as experts from other auditors through accumulated subspecialty knowledge gained from audits of similarly digitalized clients. For many industries, digitalization has fundamentally transformed how

\footnotetext{
${ }^{1}$ Following Gartner, we define digitalization as "the use of digital technologies to change a business model and provide new revenue and value-producing opportunities; it is the process of moving to a digital business." https://www.gartner.com/en/information-technology/glossary/digitalization.
} 
firms conduct their business. Business processes and information systems and internal controls have become digitalized, taking over the traditional ways of organizing accounting and administration processes (Bhimani and Willcocks 2014). Inevitably, these changes are reflected in the audits of digitalized clients. This is because, in essence, the automation and integration of business processes and accounting systems shift the focus from traditional tests of details regarding manual errors related to recording business transactions to the usage of digital technology in the testing of automated systems and their IT-based controls. However, even if no industry is immune to digitalization, its impact varies significantly across industries. Some can be clustered by the compatibility of digitalization strategies (Gandhi et al. 2016), and we argue that similarities across industries facilitate a new type of auditor expertise in auditing similarly digitalized clients. To the best of our knowledge, our research question of whether an audit partner's expertise from auditing highly digitalized - or similarly digitalized - clients results in an audit fee premium has not been previously considered in the literature.

To capture the different dimensions of how auditors' expertise affects digitalized clients, we use three alternative measures. Our first measure is based on the assumption that any industry that is highly digitalized has enough similarities to other highly digitalized industries to facilitate expertise in digitalization. Our second measure of auditor expertise in digitalization is based on similarities in industry-level digital strategies that connect different industries as digital clusters. To operationalize these two measures, we build on recent research by McKinsey (2016). For our third measure of audit partners' expertise in digitalization, we use the level of IT costs that individual audit clients have voluntarily reported in their financial statements.

We use data from Europe (Finland) and from the United States. In our main tests, we use largely hand-collected data from listed and privately held companies in Finland for a five- 
year period in 2012-2016. The audit fees are hand-collected from the footnotes of financial statements, and audit partners (as well as audit firms) are identified by the partner's signature in audit reports. Data on the auditors' years of practice as a CPA are hand-collected from the records of the Auditing Board, a governmental supervisor of the audit profession in Finland. We use Finnish data in our main tests for three reasons. First, all Finnish companies, whether listed or not, are required to register their financial statements with the public Trade Register at the Patent and Registration Office. ${ }^{2}$ Having financial information on the unlisted firms allows us to obtain more precise measures of auditor expertise (e.g., industry specialization) by calculating the auditor's market shares more accurately. Second, Finnish official sources provide us with sufficient data on individual auditors, for example, to compute the length of work experience in terms of CPA years in practice. Consequently, we can control for the generic experience of auditors (Bonner and Lewis 1990). Third, audit partners are required to personally sign the audit report, which facilitates empirical investigation at the individual audit partner level by allowing us to identify the audit partner for each engagement. Also, Finland is one of the most advanced digital economies in Europe (European Commission 2018), ${ }^{3}$ and as such, it provides a good setting to study auditors' expertise in digitalization. Finally, auditors' litigation risk is low in Finland, which reduces the likelihood that any audit fee premium associated with our digitalization measures would reflect increased litigation risk rather than the premium for expertise. ${ }^{4}$

In supplementary analysis, we use data on U.S.-listed companies to examine whether our main results based on the Finnish sample would generalize to other settings. For this purpose, we extract data from the intersection of Audit Analytics and Compustat for the years 2016-

\footnotetext{
${ }^{2}$ https://www.prh.fi/en/kaupparekisteri.html.

${ }^{3}$ European Commission, 2018, http://ec.europa.eu/information_society/newsroom/image/document/2018-20/fidesi_2018-country-profile_eng_B4400116-A9B9-4D17-9137969FEFF24981_52222.pdf.

${ }^{4}$ This is of less concern in our study, as our variables of main interest are based on client portfolios instead of client-specific characteristics. Nevertheless, there is still a remote possibility that our results will be driven portfolio characteristics rather than an audit partner's expertise. We address this alternative explanation in our additional tests.
} 
2018. Although the U.S. dataset is not as rich as the Finnish one in terms of auditor characteristics (e.g., years as a CPA), we are still able to test the main aspects of our hypothesis in the U.S. setting, thereby adding generalizability to our main conclusions.

Overall, our findings support the hypothesis that audit partners who are experts in digitalization earn a fee premium. All three measures of auditor expertise are positively associated with audit fees, and our additional analyses show that expertise in digitalization explains systematic pricing differences between audit partners. Based on our main tests (Finnish data), the estimated fee premium ranges from $13 \%$ to $35 \%$, depending on the measure of an auditor's digitalization expertise. The highest estimate is obtained using the measure that captures the auditor's expertise across industries sharing similar digitalization strategies, while the lowest estimate is predicted by the measure that is conceptually broadest and captures the general level of digitalization in the client's industry. We control for industry fixed effects and the auditor's industry specialization in the estimations, in addition to common value drivers and other auditor characteristics. The measure based on the client's reported IT costs predicts a fee premium that lies between the two extremes (26\%).

The reduced-form regression models with U.S. data yield qualitatively similar results regarding expertise in digitalization. The estimated fee premium is $63-65 \%$ in the U.S. sample, which is more than in the Finnish setting. This difference could be attributable to a more recent timespan and a different audit pricing model. Similar results are obtained using a U.S. subsample matched to the Finnish firms by size and industry. Bearing in mind some limitations of the U.S. dataset, we conclude that our findings are not limited to Finland but are generalizable to other settings.

This study contributes to an understanding of the impact of digitalization on the audit profession by conceptualizing and empirically validating client digitalization as a priced 
source of auditor expertise. Specifically, to the best of our knowledge, this study is the first to document a fee premium for an audit partner's expertise in digitalization. We also contribute to the understanding of the similarities between and within industries, which add to the knowledge of the auditor. As a result, we contribute to the literature that investigates explanations for pricing differences between audit partners (e.g., Taylor 2011; Gul et al. 2013). Second, we provide archival evidence that adds to the Bonner and Lewis (1990) model of auditor expertise by showing that auditing digitalized clients is a subspecialty knowledge similar to that arising from industry specialization. Third, we add to the literature on accounting information systems (AIS) and auditing by providing empirical measures of expertise in client-specific and industry-level digitalization. Our new measures should provide an opportunity for further research on the audit effects of digitalization.

The paper proceeds as follows. Section 2 reviews related literature and outlines the research hypothesis. Section 3 describes our setting, followed by a section explaining our research design and data. Section 5 reports our results. Section 6 concludes the paper.

\section{Related literature and hypotheses development}

\section{Effects of digitalization on audit risk}

Digitalization pressures auditors to move from traditional audit procedures to digital technology in auditing (Eilifsen et al. 2019). Professional standards in auditing instruct auditors to consider how digitalization affects audit procedures (e.g., ISA 300) and to evaluate the specific audit risks related to these effects on client accounting systems and the preparation of financial statements (e.g., ISA 315). The effect of the digitalization of business processes on audit risks is twofold. On the one hand, digitalization reduces audit risks as business processes become more structured through automation. As system-based controls and integrated databases decrease manual errors in data entry procedures, the risk of misstatements related to the manual errors also decreases. The decrease in the risk of manual 
errors, in turn, may improve the perceived quality of internal controls (Nwankpa and Datta 2012; Grabski et al. 2011). Moreover, digitalized clients' processes and information systems facilitate the usage of computer-based audit procedures, which may increase the efficiency of auditing (Pincus et al. 2017).

Digitalization, however, also increases audit risks. For example, the risks related to business interruption, process interdependency, and IT-based internal controls increase as the systems governing the business processes become automated and integrated (Hunton et al. 2004). In extreme cases, the client's operations could be paralyzed entirely if its integrated information systems stop functioning, which would expose the company to catastrophic business risk. ${ }^{5}$ Auditors also need to be more careful when considering risks related to data reliability, integrity, and security. ${ }^{6}$ The client's electronic data may be stored in the cloud or elsewhere on external servers, which brings new challenges for auditors (Cho et al. 2019). Particularly in the e-business environment, the auditor needs specific IT knowledge and skills to be able to audit electronic transactions and manage specific risks related to the digital audit environment (Kotb and Roberts 2011; Pathak and Lind 2010). Digitalization also heightens more traditional control risks, such as inadequate segregation of duties, unauthorized access, and related multi-level password controls (Han et al. 2016; Messier et al. 2004). In summary, the digitalization of client business processes and information systems has shifted audit work from manual tests of details and other traditional procedures to digitalized tests of IT-based controls and information systems.

\footnotetext{
5 The recent logistical collapse of Oriola, a Finnish listed pharmaceutical company, was caused by the introduction of a new ERP system in 2017, and it shows the magnitude of these system risks on company operations. See https://erpinnews.com/erp-system-failure-crippled-finnish-pharma.

${ }^{6}$ Before starting analyses of accounting data, it is essential for auditors to be sure that it is complete, accurate, without duplications, and without manual or automatic errors. The absence of hardcopy documents directs auditors to work with electronic data during the audit process. Consequently, extracting data from different systems requires auditors to assess credibility of the source. If data are easily accessible, complete, accurate, and compatible for further analysis, it will make the audit less complicated and thus decrease audit risks.
} 
The audit profession has attempted to cope with the new audit risks arising from the digitalization of client operations and systems by digitalizing their own auditing services. Audit firms have invested heavily in the development of digitalized auditing tools such as data analytics, and they have hired IT experts to assist auditors with applying newly developed auditing technologies (Eilifsen et al. 2019). Audit firms also have in-house knowledge-sharing systems that facilitate the transfer of knowledge throughout the firm (Chow et al. 2008; Murthy and Kerr 2004; and Vera-Munõz et al. 2006). The transfer of knowledge aims to promote best practices (Dowling 2009) and auditing "style" of the firm (Francis et al. 2014; Lemon et al. 2000). However, while aiming to improve and harmonize the audits, it may also restrict the audit partners' discretion in their judgment and decisionmaking (Francis et al. 2014). In sum, audit firms encourage and support their auditors to adopt in-house digital technologies in auditing (Eilifsen et al. 2019).

\section{Audit partner expertise in digitalization}

Because new auditing technology and the assistance of IT specialists are equally available to all audit partners in the firm, how could any audit partner become recognized as an expert among digitalized clients and be able to earn an audit fee premium? Paradoxically, to be able to involve IT experts in an audit engagement, the partner him/herself needs to have sufficient IT knowledge. Auditing involves a great deal of judgment and decision-making. An audit partner is responsible for making decisions not only about how the audit is conducted but also for reviewing the audit team's work, including that of the IT specialists. Therefore, the audit partner's decision to involve an IT specialist on an audit engagement depends on the partner's own ability to supervise and interact with the IT specialist (Hux 2017; Bauer et al. 2019). Moreover, prior literature suggests that auditors who have less knowledge and experience in IT fail to identify significant audit risks related to digitalized systems, and therefore, they refrain from involving IT experts even if it were warranted (Brazel and 
Agoglia 2007). Finally, an audit partner with less IT knowledge may find it challenging to translate an IT specialist's work into audit evidence in audit work papers, and therefore, they may decide to use traditional audit procedures instead of digitalized ones, even if the digitalized methods are more efficient (Eilifsen et al. 2019). In essence, working with the IT experts requires a sufficient level of IT understanding, audits of IT systems, and data analytics to enable the partner to communicate and utilize the work of experts (Hux 2017).

The more digitalized the client's business processes and information systems, the more inefficient the traditional audit procedures, and the more valuable the partner's ability to utilize IT specialist's knowledge and skills. In the most extreme cases, an audit using traditional audit procedures is not possible at all. This is the case with clients in e-business, which requires not only an understanding of underlying digital systems, data, and access mechanisms but also a digital auditing approach instead of a traditional one (Kotb and Roberts 2011).

Digitalization is a multi-faceted phenomenon, having a differential effect on different industries. Some industries are similar in terms of highly digitalized business, whereas others, even if moderately digitalized, may share a similar digital strategy (Gandhi et al. 2016). Building on the concept of subspecialty knowledge (Bonner and Lewis 1990), ${ }^{7}$ which accumulates through the auditing of similar clients (Zerni 2012), we argue that audit partners who have specialized in similarly digitalized clients gain reputation capital as expert auditors among those clients and industries, resulting in a fee premium (Moizer 1997). Similarities among clients may occur through a degree of overall digitalization, or through the digital strategy of the industry.

These considerations lead to our hypothesis:

\footnotetext{
${ }^{7}$ Regarding this subspecialty knowledge, Bonner and Lewis $(1990,5)$ note that it is "acquired by persons who have experience with specific audit clients, with certain industries, and/or firm training in those specialized areas," and that "such knowledge is less likely to be acquired through general instruction or experience and, thus, is unlikely to be held by all auditors with a given level of experience" [italics added].
} 
HYPOTHESIS. Audit partners who have expertise in highly-or similarly-digitalized

clients earn a fee premium over their non-specialist counterparts.

\section{Institutional setting}

We use data from two distinct geographical locations: Finland and the United States. We use Finnish data in our main tests and U.S. data in our additional tests to evaluate the generalizability of our findings. Finland provides a good setting to study auditor expertise in digitalization on the audit partner level for three main reasons. First, as described earlier, the Finnish setting provides us with high-quality data suitable for our study. Finnish data allow us to calculate more complete client portfolios as financial statements and audit reports are also publicly available for privately held companies. Additionally, the audit partners are required to personally sign the audit report, which allows us to identify the audit partner for each engagement and facilitate an empirical investigation at the individual audit partner level. In addition, we have access to the CPA registers of the Finnish Auditing Board, by which we are able to control for an audit partner's general working experience as a CPA (Bonner and Lewis 1990; Cahan and Sun 2015). In essence, Finnish data allow us to use a larger set of controls for confounding effects related to client characteristics, attributes of client portfolios, and individual audit partner characteristics. Second, in Finland, there should be sufficient variation in the degree of digitalization for both individual audit partners and their clients to facilitate an empirical investigation of our research question. Finnish auditors especially have a strong incentive to invest in their knowledge and skills in client digitalization as Finland is one of the most advanced digital economies in Europe (European Commission 2018). ${ }^{8}$ Finland ranks highest in companies' IT integration according to the IMD World Digital Competitiveness Ranking 2018. Nearly one-half of Finnish enterprises in services and one-

${ }^{8}$ European Commission, 2018, http://ec.europa.eu/information_society/newsroom/image/document/2018-20/fidesi_2018-country-profile_eng_B4400116-A9B9-4D17-9137969FEFF24981_52222.pdf. 
third in manufacturing assess digitalization to be of at least medium importance for the enterprise's business model in the near future (Statistics Finland 2018a). ${ }^{9}$ To validate the argument on the importance of client digitalization, we use text mining techniques on a database of 18,608 annual reports written in English from 5,888 European firms in 20142017 to investigate the usage of digitalization narratives in formal business communication. Our text mining results show that Finland ranks the highest in the proportion of firms mentioning digitalization in a business context. Namely, two-thirds $(67 \%)$ of the Finnish firms in our annual reports database write about digitalization in relation to customers, business, growth, and strategy, followed by Germany (64\%), France (54\%), Switzerland (51\%), and Sweden (49\%). Digitalization is also mentioned sooner and in a more relevant setting in the Finnish annual reports than in any of the other 43 countries in the database. ${ }^{10}$ These results are available upon request.

Finally, Finland is characterized as being a mildly litigious (Niemi 2002) and individualistic country, having a relatively high score (63) on Hofstede's scale. ${ }^{11}$ These two characteristics of institutional settings have important implications for the auditing environment in Finland. Auditors' low litigation risk reduces the likelihood that any audit fee premium associated with our digitalization measures would reflect an increased litigation risk rather than the premium for expertise. Regarding the latter, a high level of individualism emphasizes the roles of individuals - audit partners, in our case - in decision-making.

The U.S. setting differs from the Finnish one in at least three important aspects. First, litigation risk is clearly higher in the United States as it is the most litigious audit environment in the world (Francis 2004). Second, audit fees are highest in the U.S. (Eierle 2019), which may at least partially relate to the high risk of litigation. Third, the United

\footnotetext{
${ }^{9}$ Statistics Finland, 2018a, https://www.stat.fi/til/icte/index_en.html.

${ }^{10}$ Relevance measured with Okapi BM25F, a metric used by search engines to rank matching documents according to their relevance to a given search query.

11 Hofstede, G. (2011). Dimensionalizing cultures: The Hofstede Model in context. Online Readings in Psychology and Culture, 2(1) https://www.hofstede-insights.com/country-comparison/the-usa.
} 
States is a leading global economy. Firms operating in larger economies tend to be larger, providing auditors with stronger incentives to develop their expertise.

\section{Method and sample}

\subsection{Model Specification and Variables}

\section{Model specification}

To test our hypothesis that audit partners who have specialized in highly digitalized clients earn a fee premium, we regress audit fees on our measures of audit partner digitalization expertise and a set of variables controlling for other audit partner and client characteristics based on the prior audit fee literature (Francis 1984; Hay et al. 2006; Simunic 1980). More specifically, using unbalanced panel data and clustering the standard errors by firm (Peterson 2009), we estimate the following empirical model of audit fees using OLS regression:

$$
\begin{aligned}
\text { LNFEE }_{i t}=\beta_{0} & +\beta_{1} \text { DIGI_SPEC } C_{j t}+\beta_{2} I N D_{-}{ }_{S P E C} C_{j k t}+\beta_{3} P O R T F O L I O_{j t}+\beta_{4} P U B_{j t} \\
& +\beta_{5} D I G I \_I N D_{k}+\beta_{6} L N T A_{i t}+\beta_{7} R E C_{i t}+\beta_{8} L O S S_{i t}+\beta_{9} S U B_{i t} \\
& +\beta_{10} L I S T E D_{i t}+\beta_{11} I M P_{i t}+\beta_{12} B I G 4_{i t}+\beta_{13} F E M A L E_{j} \\
& +\beta_{14} \text { CHANGE } E_{i t}+\beta_{15} E X P_{j t}+\text { year fixed effects } \\
& + \text { industry fixed effects }+\varepsilon_{i t}
\end{aligned}
$$

where the dependent variable, the natural logarithm of the audit fee $\left(L N F E E_{i t}\right)$, is regressed on our measures of auditor expertise in digitalization (DIGI_SPEC $\left.C_{j t}\right)$ and a set of control variables for various auditor and client-specific characteristics. Subscripts $i, j, k$, and $t$ in the model specification refer to the client, audit partner, the client's industry, and time, respectively. All variables are defined in detail in the Appendix.

Measures of specialization in digitalized clients 
We use three measures of auditor expertise in digitalized clients. First, our broadest measure of an auditor's digitalization expertise (DIGI_SPEC1) is based on the assumption that any industry that is highly digitalized has enough similarities with other highly digitalized industries to allow auditors to accumulate subspecialty knowledge (Bonner and Lewis 1990) that is relevant when auditing highly digitalized clients. To assess the level of digitalization in each industry (Gandhi et al. 2016; Edeling and Himme 2018), we use the Industry Digitization Index by the McKinsey Global Institute (McKinsey 2016). Table 1 shows the index for the industries in our sample, running from zero (construction industry) to seven, which is the highest level of digitalization (ICT and media industries). ${ }^{12,13}$ We define highly digitalized industries as those with an index value of at least five (DIGI_IND > 4). As seen in Table 1, six industries have an index value higher than four (ICT, media, multiple industry, professional services, wholesale trade, and advanced manufacturing). This means that an indicator variable DIGI_SPEC1 takes the value of one if, in an individual audit partner's portfolio, the ratio of audit fees from highly digitalized industries to total audit fees at year $t$ or $t-1$ is higher than the median ratio of all auditors, and zero otherwise.

\section{[TABLE 1]}

Our second measure of auditor expertise in digitalization (DIGI_SPEC2) is based on similarities in industry-level digital strategies that connect different industries as digital clusters. These six different clusters, shown in Table 1, are adopted from McKinsey (2016), and they are based on commonalities among eight distinct digital strategies (for discussion, see Gandhi et al. 2016). The distinctive digital strategies identified by McKinsey (2016) relate to (i) digital assets, i.e., how much companies invest in hardware, software, data, and

\footnotetext{
${ }^{12}$ Following prior fee studies, we exclude financial and insurance service industries. Regarding firms having more than one main industry, we label them as multi-industry. This industry class has the same relatively high index as Wholesale trade, as groups operating in multiple industries are typically relatively highly digitalized.

13 The list of industries is not in ascending order of the index; rather, it is organized by the six clusters of industries.
} 
IT services and how much of their asset base is digitalized in the form of smart buildings, connected vehicle fleets, big data, and IoT systems; (ii) digital usage, i.e., the extent to which companies engage digitally with customers and suppliers in transactions, interactions, processes, and market-making; and (iii) digital labor, i.e., the degree to which companies put digital tools in the hands of their employees in the form of digital spending on the workforce, increasing digital human capital, and digitalizing work. To summarize, the six digital clusters that underpin DIGI_SPEC2 are based on similarities in the eight digital strategies listed above.

As Table 1 shows, industries of ICT, media, and professional services are clustered as knowledge-intensive industries. These industries rank very highly across all eight digital strategies; hence, they are also highly ranked in the total digitalization index, with scores ranging from five (professional services) to seven (ICT and media). In the second cluster of capital-intensive industries, there is more variance in terms of the degree of digitalization, as the digitalization index ranges from three to six. Industries like wholesale (six) and advanced manufacturing (five) score highest in the degree of digitalization. In contrast, industries like utilities (four), mining (two), and basic goods manufacturing (three) score lower, as they are in the early stages of connecting their physical assets to digital technologies (McKinsey 2016). Also, industries in the cluster of service industries have a relatively broad range of scores in terms of the digitalization index. Personal and local services and government score highest with an index of four, whereas agriculture (one) and construction (zero) are lowest on the index in this cluster. In general, the service industries cluster is still very much in progress in digitalizing customer transactions (McKinsey 2016). Industries in the Business-to-business (B2B) cluster are on the low end of the digitalization index, with scores ranging from two (transportation and warehousing) to four (chemicals and pharmaceuticals and utilities). The low overall scores mean that no industry in the $B 2 B$ cluster is classified as highly digitalized 
$(D I G I I N D>4)$. In general, many industries in the $B 2 B$ cluster (e.g., mining, transportation, and warehousing) are lagging in digitalizing the interactions with customers and suppliers (McKinsey 2016). It may relate to the specific characteristic of $B 2 B$ industries, in which firms typically have only a few large customers and suppliers, and therefore, traditional face-toface negotiations with customers and suppliers may be more cost-efficient than interactions via digital technology. The cluster of labor-intensive industries has a relatively broad range of index scores, ranging from zero (construction) to four (e.g., retail trade). In these industries, the wages of the workforce are relatively low, weakening the incentives to invest in expensive digital technology.

Looking at Table 1, it is evident that the same industry (and, hence, a client firm) can be included in more than one digital cluster. This observation is important because it differentiates our cluster-based digitalization expertise from ordinary industry specialization. For example, the industry of basic goods manufacturing belongs to both the cluster of capital-intensive industries with the potential to digitalize their assets, and to the cluster of $B 2 B$ with the potential to increase digital interaction with customers. Hence, each client appears in only one audit partner's portfolio per year, but within that portfolio, the client's audit fees may contribute to the partner's market shares in several digitalization clusters. Then, an indicator variable DIGI_SPEC2 takes the value of one if the auditor has a higherthan-median market share in audit fees in a given digital cluster, and zero otherwise.

Our third measure of expertise in digitalization (DIGI_SPEC3) is based on an audit client's IT expenses, as reported in the financial statement footnotes. IT expenses include investments in hardware, software, and IT personnel. The strength of this measure is that it captures the variation between the companies operating in the same industry. ${ }^{14}$ However, the

\footnotetext{
${ }^{14}$ For example, Uber Technologies, Inc. has completely digitalized business processes, whereas most other taxi service providers are clearly less digitalized. The same applies to Amazon.com, Inc. in comparison to other retailers.
} 
downside of this measure is that the disclosure of IT expenses is not mandated by the Finnish GAAP, leaving us with a limited subsample of voluntarily reported IT expenses (382 client firm-years, 327 with all the data for the regressions). Using the information on IT expenses from those 382 companies, we calculate our digitalization index for auditor $j$ in year $t\left(D I_{j t}\right)$. First, we scale IT expenses (ITE) by total operating expenses (TOE) and calculate the average ratio for each auditor and year.

$$
D I_{j t}=\frac{\sum_{i j t}(I T E / T O E)}{\sum_{i j} N_{I T}}
$$

Then, we define auditors as digitalization specialists if their digitalization index $\left(D I_{j t}\right)$ is higher than the median of all individual auditors' indexes in a given fiscal year. Specifically, DIGI_SPEC3 equals one if $D I_{j t}$ in year $t$ or $t-1$ is larger than the sample median, and zero otherwise. Despite the downside discussed above, the use of IT expenses is appealing as it is a more direct measure of the level of digitalization for a given company than other available (industry-based) measures.

\section{Control variables}

To control for confounding effects, we augment our regression models with a large number of variables capturing relevant client portfolio characteristics, client characteristics, and individual audit partner characteristics based on prior fee studies (Hay et al. 2006). We also control for year and industry fixed effects.

Portfolio characteristics. We use three variables to control for relevant aspects of the audit partner's client portfolio that may have an effect on audit fees: (1) industry specialization (IND_SPEC), defined as an indicator variable that equals one if the audit fees 
of the audit partner $j$ for industry $k$ in year $t$ are higher than the mean, and zero otherwise ${ }^{15}$; (2) client portfolio size (PORTFOLIO), measured as the natural logarithm of the total assets of all clients audited by audit partner $j$ in year $t$ (Sundgren and Svanström 2014) ${ }^{16}$; and (3) specialization in listed companies (Zerni 2012), defined as the proportion of publicly listed clients in the portfolio of auditor $j$ in year $t(P U B)$. We expect a positive coefficient for all of these variables.

Client characteristics. In addition to industry fixed effects, we control for seven relevant client characteristics that may affect audit fees: (1) the digitalization level of the industry that the client operates in (DIGI_IND), with values from zero (lowest) to seven (highest) ${ }^{17} ;(2)$ client size (LNTA), measured as the natural logarithm of total assets; (3) ratio of total receivables to total assets $(R E C)^{18}$; (4) loss-making firms (LOSS); (5) complexity of client operations $(S U B) ;(6)$ the economic importance of the client to the partner $(I M P)$, measured as the relative size of the client in the partner's portfolio; and (7) listing status (LISTED), an indicator variable that equals one for listed companies. We augment the model with DIGI_IND to control for the effect of digitalization at the client level. As digitalization may increase audit efficiency (Pincus et al. 2017) but also some particular audit risks, we predict no sign for the coefficient of DIGI_IND since it has potentially two opposite effects on audit effort. For other client-specific control variables, except for IMP, we expect positive coefficients as client size, complexity, and an inherent risk increase audit effort required (Hay

\footnotetext{
15 The most employed proxies for the auditor's specialization are those based on market shares, measured as audit fees or audited total assets (DeFond et al. 2000; Audousset-Coulier et al. 2016).

16 PORTFOLIO and IMP are highly correlated with each other. To evaluate how this affects our results, we estimated our models without PORTFOLIO or IMP. Our results (untabulated) remain qualitatively the same, indicating that multicollinearity regarding these variables is not a serious problem.

${ }^{17}$ Our scores are based on the Industry Digitization Index by the McKinsey Global Institute (Gandhi et al. 2016).

${ }^{18}$ For tests with the U.S. data, we use the sum of receivables and inventories scaled by total assets (INVREC). Replacing REC with INVREC in our main tests with Finnish data yields a slightly smaller sample size, but our results remain qualitatively the same.
} 
et al. 2006; Krishnan 2005). For IMP, we expect a negative coefficient as there may be fee discount pressures for economically important clients.

Auditor characteristics. We control for four auditor-related characteristics with the following variable specifications: (1) an indicator variable that equals one for audits by partners working for Big 4 audit firms (BIG4); (2) an indicator for the gender of an audit partner (FEMALE) that equals one if the partner is female; (3) an indicator that equals one if the audit partner has changed from the previous year (CHANGE); and (4) general experience of the partner (EXP) accumulated over the years of practice (Bonner and Lewis 1990), measured as the number of years as a CPA. We expect BIG4, EXP, and FEMALE to have positive coefficients (Hay et al. 2006; Cahan and Sun 2015; Ittonen and Peni 2012) and CHANGE to have a negative coefficient (DeAngelo 1981; Francis 1984).

\subsection{Data, sample selection, and descriptive statistics}

\section{Data sources and sample selection}

We collected audit fees, partner characteristics, and IT cost data for 2012-2016 from the footnotes of the financial statements of Finnish public and private companies. Industry-level digitalization measures are from McKinsey (2016), following Gandhi et al. (2016) and Edeling and Himme (2018). After excluding the smallest companies, our initial sample was 3,390 firm-year observations, from which 382 reported IT costs. ${ }^{19}$ We further exclude financial and insurance companies and merge the remaining sample with financial statement data from the Amadeus database. Combined, the sample attrition due to missing values and exclusion of financial and insurance industries leaves us with a final sample of 2,223 firmyear observations, from which 327 report IT costs. Table 1 shows the proportion of the final sample by industry. Wholesale trade, Professional services, and Basic goods manufacturing

\footnotetext{
${ }^{19}$ We exclude the smallest companies, whose total assets are less than five million euros.
} 
are the most common industries in our final sample, representing $19 \%, 17 \%$, and $11 \%$, respectively, of our observations $(431 ; 380 ; 237)$.

\section{Descriptive statistics}

Table 2 presents descriptive statistics for the variables used in our analyses. The average logarithmic audit fee (LNFEE) is 11.18. Audits conducted by auditors with industry-level digitalization expertise (DIGI_SPEC1) represent 54.5\% of the sample (1,085 clients), auditors with digital-cluster-level expertise (DIGI_SPEC2) are engaged in $50.1 \%$ of the audits in our sample (1,114 clients), and $48 \%$ of the sample audits are conducted by clientlevel digitalization experts (DIGI_SPEC3, 157 clients from the subsample of 327 clients reporting IT costs). The average industry digitalization index (DIGI_IND) is 4.5, where zero is the lowest digitalization level and seven the highest. Clients of industry-specialist audit partners (IND_SPEC) compose $49.7 \%$ of the sample. The average logarithmic total assets audited by a partner is 20.7 (PORTFOLIO). In an average partner's portfolio, $20 \%$ of the audited clients are publicly listed firms $(P U B)$. The average client size measured as the natural logarithm of total assets $(L N T A)$ is 18.8 . The mean ratio of receivables to total assets $(R E C)$ is $17.3 \%$. Regarding financial performance, $21.9 \%$ of the firm-years report a negative net profit $(L O S S)$. The average square root of the subsidiaries $(S U B)$ is 2.27 , corresponding to approximately five subsidiaries per firm. Listed companies comprise $19.8 \%$ of the total sample. On average, the largest client's assets are $34.6 \%$ of the total assets audited by a given partner (IMP). Regarding the auditors' characteristics, the vast majority (91.9\%) work for Big

4 accounting firms, while the number of female auditors is relatively low (18.9\%). The 
number of auditor changes $(C H A N G E)$ is $14 \%$, implying a change every seven years. The average length of a career as a certified public accountant $(E X P)$ is 19 years. ${ }^{20}$

[TABLE 2]

\section{Results}

\subsection{Correlations}

Table 3 presents Pearson and Spearman correlations as well as Variance Inflation Factors. Regarding our variables of main interest, auditor expertise in digitalization (industrylevel DIGI_SPEC1, digital-cluster-level DIGI_SPEC2, and client-level DIGI_SPEC3) are positively correlated with audit fees (LNFEE), as expected, providing tentative support for our hypothesis. Our digitalization expertise measures are also positively correlated with each other, providing further evidence for the validity of these variables. Audit fees (LNFEE) are highly correlated with total assets ( $L N T A)$ and the number of subsidiaries $(S U B)$, as expected. Regarding other control variables, the highest correlation (67\%) is between LISTED and PUB (which is smaller than the overall $R^{2}$ of the full model, Judge et al. 1988). The Variance Inflation Factors shown on the diagonal of the matrix suggest that multicollinearity is not a problem, given that all VIF scores are well below the criterion value of 10.0 suggested by Menard (1995) and many others. The removal of PORTFOLIO, having the highest VIF score of 6.57 , does not change our results regarding the variables of interest.

[TABLE 3]

\subsection{Regression Results}

Table 4 presents the regression results for our two industry-based digitalization expertise measures (DIGI_SPEC1 and DIGI_SPEC2). The $t$-values of the regression coefficients are

\footnotetext{
${ }^{20}$ In Finland, there are three types of auditor certifications. We focus on first-tier KHT auditors that are allowed to audit any kind of client, including listed companies. The other two types of certified auditors are not allowed to audit listed companies. Almost all KHT auditors work for Big 4 audit firms.
} 
based on standard errors clustered by firm (Peterson 2009). Overall, statistically significant positive coefficients on DIGI_SPEC1 and DIGI_SPEC2 provide support for our hypothesis that audit partners who have specialized in highly digitalized clients earn a fee premium. More specifically, the coefficient of DIGI_SPEC1 $(0.123, t=2.71)$ implies that audit partners with industry-level digitalization expertise charge over $13 \%$ higher audit fees on average than the other auditors (model 2). For DIGI_SPEC2, the coefficient $(0.298, t=5.71)$ suggests that, compared to other auditors, the audit partners with digital cluster-level expertise charge almost 35\% higher audit fees from their clients on average (model 3).

\section{[TABLE 4]}

Table 4 reports several important findings regarding the control variables. Most importantly, and related to our variables of interest, we observe a statistically significant positive coefficient on industry specialist partners (IND_SPEC) in all models. Consistent with prior studies, this finding suggests that industry specialist auditors earn a higher fee premium compared to non-specialist auditors. Perhaps more interestingly, models 2 and 3 indicate that the fee premium associated with our digitalization specialist measures coexist with the positive fee effect of industry specialization in a joint model. In statistical terms, our DIGI_SPEC variables explain the variation in audit fees independently of IND_SPEC, which implies that there are two distinct sources of a specialization premium. Regarding the partners' client portfolio characteristics, having public clients in the portfolio expectedly increases audit fees, as shown by the positive coefficient on PUB in all three models. The coefficient on PORTFOLIO is negative, indicating that client portfolio size is negatively associated with fees. This seemingly counterintuitive result can be explained by recognizing that the negative sign reflects the decreasing economies of scale for larger client portfolios, holding constant the size of a marginal client. 
The client characteristic of particular interest in our study is the degree of digitalization of the industry in which the client operates (DIGI_IND). The coefficient of DIGI_IND is positive and significant, and it indicates that clients in higher digitalized industries pay higher audit fees. For client size (LNTA), risk (REC and LOSS), complexity (SUB), and public listing status (LISTED), the coefficients of these variables have positive signs, as expected. The variable for the relative importance of the client (IMP) has an insignificant or marginally negative coefficient $(p$-value $<.10)$, which implies fee pressure from economically important clients.

Regarding auditor characteristics, BIG4 has an expected positive sign, indicating that Big 4 accounting firms' fees are about one-third higher. Also, FEMALE has a positive sign in model 3, indicating higher fees, but this is less clear in other models. The coefficients on audit partner change (CHANGE) and the audit partner's general experience measured as CPA years $(E X P)$ remain insignificant. Regarding our finding for general experience, it is consistent with the conclusion of Bonner and Lewis (1990) that general knowledge is not as important in developing auditor expertise as subspecialty knowledge accumulated through the audits of similar clients.

\section{[TABLE 5]}

Table 5 shows the regression results from the specialist model based on voluntarily reported IT costs by a subsample of audit clients. Consistent with the other two DIGI_SPEC specifications, the coefficient on DIGI_SPEC3 is positive and statistically significant $(0.233$, $t=2.12$ ). This result implies that audit partners who have specialized in clients with abovemedian IT costs earn a $26 \%$ fee premium on average after accounting for confounding factors, thus providing further support to our research hypothesis. The control variables, 
including industry specialization IND_SPEC, have expected signs or are statistically insignificant from zero.

In summary, all models provide consistent support for our hypothesis that audit partners who have specialized in highly digitalized clients earn a fee premium, as shown by the positive and statistically significant coefficients on all three versions of DIGI_SPEC. Each of these three measures captures a slightly different aspect of digitalization: the degree of digitalization of an industry, the cluster of similar digital strategies, and an individual client's IT expenses. As we find a positive and significant association between audit fees and all three measures of DIGI_SPEC, we interpret these findings to be supportive of our conjecture that digitalization provides an audit partner with an opportunity to gain expertise that extends beyond specialization in single industries.

\subsection{Additional Analyses}

We conduct several additional analyses to further assess the robustness and generalizability of our results. First, following Gul et al. (2013), we analyze average pricing differences between individual audit partners (i.e., partner fixed effects) to rule out an alternative explanation that our findings could be driven by client or audit firm characteristics rather than the audit partner's expertise in digitalization. This analysis is conducted in two steps. First, we estimate the audit partner fixed effects using the following audit fee model:

$$
\begin{aligned}
& \text { LNFEE }_{i t}=\beta_{0}+\beta_{1} \text { PORTFOLIO }_{j t}+\beta_{2} \text { PUB }_{j t}+\beta_{3} \text { LNTA }_{i t}+\beta_{4} \text { REC }_{i t}+\beta_{5} \text { LOSS }_{i t} \\
& +\beta_{6} S U B_{i t}+\beta_{7} L_{I S T E D} D_{i t}+\beta_{8} I M P_{i t}+\beta_{9} B I G 4_{i t} \\
& +\beta_{10} C H A N G E_{i t}+\text { partner fixed effects }+ \text { audit firm fixed effects } \\
& + \text { year fixed effects }+ \text { industry fixed effects }+\varepsilon_{i j t}
\end{aligned}
$$

Next, we regress the estimated audit partner fixed effects on various specifications of our variable of main interest (DIGI_SPEC) and other relevant partner characteristics as follows:

$$
\hat{\beta}_{j}=\gamma_{0}+\gamma_{1} D I G I S P E C_{j t}+\gamma_{2} I N D \_S P E C_{j k t}+\gamma_{3} F E M A L E_{j}+\gamma_{4} E X P_{j t}+\hat{v}_{j k t}
$$


where $\hat{\beta}_{j}$ is the estimated pricing power of partner $j$ from Equation (3), holding constant the factors unrelated to the partner's individual characteristics. In panel A of Table 6, models 2 and 3 show the extent of the additional variation in audit fees explained by the audit firm and the audit partner fixed effects, in comparison to the baseline model 1, which includes industry and time fixed effects. Specifically, model 2 in panel A shows that adding audit firm $(N=30)$ fixed effects increases the adjusted $R^{2}$ by 1.8 percentage points compared to the baseline model 1. As we have a separate indicator variable for audits by Big 4 accounting firms $\left(B I G 4_{i t}\right)$ in the first-step model, there is not much variation left for individual audit firm fixed effects, bearing in mind that Big 4 firms are dominant in the Finnish audit market $(91.9 \%$ in our sample). Model 3 is augmented with audit partner fixed effects, which increases the adjusted $R^{2}$ by another 5.9 percentage points.

\section{[TABLE 6]}

Panel B of Table 6 shows a positive association between the audit partner fee premium and all three specifications of auditor specialization in digitalization (DIGI_SPEC). Specifically, the estimated effect of auditor specialization based on the industry-level measure DIGI_SPEC1 (model 1) is $0.202(t=2.78)$, the effect based on the cluster-level measure DIGI_SPEC2 (model 2) is $0.163(t=2.09)$, and the effect based on the client-level measure DIGI_SPEC3 (model 3) is $0.170(t=2.08)$. Regarding industry specialization, the coefficients of IND_SPEC are positive in all three models, providing consistent evidence that industry specialist audit partners earn a higher fee premium over non-specialists. Again, it is noteworthy that industry and digitalization specification capture their own distinctive audit fee premia, irrespective of the exact specification of the latter. In line with our main tests, auditor gender and overall experience are not associated with pricing differences across individual auditors as the coefficients of FEMALE and EXP lack statistical significance. 
For the second additional test, we examine whether our main results based on the Finnish sample would generalize to other settings. For this purpose, we use available data on U.S. listed firms from the Audit Analytics and Compustat databases for the 2016-2018 period, and we re-estimate equation (1) using the U.S. sample (12,185 firm-years; 4,486 unique firms). To mitigate any concerns that the results on the U.S. sample are an artifact of cross-country differences in relative firm or industry sizes, we conduct supplementary analysis using a subsample (2,910 firm-years; 1,031 unique firms) of U.S. firms matched to the Finnish sample by size and industry (untabulated).

Table 7 presents descriptive statistics for the full U.S. sample. The average of logarithmic audit fees (LNFEE) is 13.59. Audits conducted by the audit partners with industry-level digitalization expertise (DIGI_SPEC1) represent $46.1 \%$ of the sample, which is slightly lower than the share of audit partners with digital cluster-level expertise (DIGI_SPEC2) $(49.3 \%$ of the audits in our sample). The mean of the industry digitalization index (DIGI_IND) is 4.9, ranging between two and seven. The clients of industry-specialist audit partners (IND_SPEC) compose $29.9 \%$ of the sample. The size of an average client portfolio (PORTFOLIO), measured as the natural logarithm of total assets of all clients audited by the partner, is 21.1 . The mean of the client size measured as the natural logarithm of total assets $(L N T A)$ is 19.8 . The mean of receivables and inventory is $19.1 \%$ of the total assets (INVREC). Regarding financial performance, $48.6 \%$ of the firm-years report losses (LOSS). The mean of the square root of segments $(S E G)$ is 2.61 , meaning that, on average, firms have approximately seven segments. Regarding client importance, the mean value of $(I M P)$ is 0.506 , showing that, in the average client portfolio, the largest client's assets are $50.6 \%$ of the total audited assets by the audit partner. Regarding the auditors' characteristics, the majority of audit partners (65\%) work for Big 4 accounting firms. The relative number of initial audits is $9 \%$, as shown by the indicator variable for auditor changes (CHANGE). 
The U.S. sample differs from the Finnish one in two main dimensions. As documented by Eierle et al. (2019), audit fees in the U.S. are considerably higher than anywhere else in the world, especially vis-à-vis the Nordic countries. Also, the average firm size is significantly larger in the U.S. compared to Finland, but this difference is accounted for in the matched sample approach. Tables 2 and 7 show overlapping interquartile ranges for the rest of the variables, indicating statistically insignificant differences in other dimensions.

\section{[TABLE 7]}

Table 8 reports the regression results for the U.S. sample, showing positive associations between audit fees and audit partner expertise in digitalization, both at the industry (DIGI_SPEC1) and the digital cluster levels (DIGI_SPEC2). The effect of partner expertise in digitalization in the U.S. setting seems even stronger than in the Finnish one, as shown by the increased magnitude of the coefficients on DIGI_SPECl $(0.501, t=22.35)$ and DIGI_SPEC2 $(0.491, t=21.51)$. The coefficients imply that industry-level (cluster-level) digitalization expert auditors are associated with 65\% (63\%) higher audit fees on average than their non-expert counterparts. Consistent with prior findings, industry specialist auditors earn a fee premium compared to non-specialist auditors, as shown by the positive coefficient of IND_SPEC in all three models. Also, the size of a partner's client portfolio (PORTFOLIO) is positively associated with audit fees. Regarding client firm characteristics, client size (LNTA), risk (INVREC and LOSS), and complexity (SEG) have positive signs, as expected. The Big 4 accounting firms (BIG4) charge higher audit fees, which is consistent with prior studies. Unlike in Finland, competition in the U.S. seems more aggressive, as suggested by the negative coefficient of an indicator variable for auditor changes (CHANGE) in all three models. The results are similar when we use the size- and industry-matched subsample instead of the full sample, indicating that the results are not driven by cross-country 
differentials in firm size or industry composition. The results for the matched subsample are available upon request.

\section{[TABLE 8]}

Third, we estimate the client-level model (DIGI_SPEC3) using our full sample of Finnish client firms instead of the subsample of client firms who voluntarily report IT costs (see Table 5). We employ the multiple imputation procedure (Rubin 1987) to control for the statistical effects of non-reported IT costs. ${ }^{21}$ The results (untabulated) remain qualitatively the same, showing that our results on the client-level analysis extend (at least statistically) to the whole sample of Finnish listed and private firms.

Finally, we use an alternative cutoff point to define expertise. Instead of the median value of the individual auditor's average digitalization index, we use the mean value as the cutoff point for the auditor expertise measures (DIGI_SPEC1, DIGI_SPEC2, and DIGI_SPEC3) and the industry specialization measure (IND_SPEC). Again, our results (untabulated) remained qualitatively the same, showing that our findings are not sensitive to a specific cutoff point.

\section{Conclusions}

Digitalization has fundamentally transformed business processes and information systems in many industries. We argue that the digitalization of business has created an opportunity for auditors to differentiate themselves as experts in digitalized audits. Building on Bonner and Lewis's (1990) concept of subspecialty knowledge, we hypothesize that audit partners who

\footnotetext{
${ }^{21}$ Given the large number of missing IT costs, we perform this analysis using available data and those with multiple imputations to generate data for firms with missing IT costs. In the latter approach, we use the multiple imputation procedure to impute multiple plausible values for the missing IT cost observations. The plausible values are drawn from the observed, multivariate distribution of IT costs and Operational Expenses, controlling for industry and year. The definition of DIGI_SPEC3 remains the same. The variation in the estimated regression coefficients caused by multiple imputations is added to the standard errors as an additional source of parameter uncertainty.
} 
have specialized in highly - or similarly - digitalized clients earn higher fees than other audit partners. Using three digitalization proxies, a large set of control variables, different statistical approaches, and two distinct geographical samples, we find consistent support for this hypothesis. The baseline results indicate that audits performed by partners specialized in digitalization are associated with 13-35\% higher audit fees than audits by non-specialists. In our sample of U.S. audits, we find that the audit fee premium associated with digitalization ranges from $63 \%$ to $65 \%$. The use of separate datasets from two different countries, and the fact that the digitalization premium coexists with known value drivers such as industry specialization, adds credibility and generalizability to our results.

This study contributes to an improved understanding of how increased client digitalization, especially in terms of auditor experience, alters audit pricing. Prior literature on auditor experience has focused on the role of general working experience (e.g., Cahan and Sun 2015) and industry specialization (e.g., Zerni 2012) in explaining the pricing differences between audit partners (e.g., Taylor 2011; Gul et al. 2013). We show that specializing in digitalization, which fundamentally changes clients' business models and related technologies, provides auditors with an opportunity to deliver value to the client that extends beyond the boundaries of industry knowledge and is complementary to general knowledge accumulated by years in the profession.

Regarding the limitations of our study, we face a challenge that is common to studies on the relationship between audit fees and auditor specialization; namely, an alternative explanation for our findings could be that the documented fee premium is driven by an omitted client or audit firm characteristic, which correlates with our measures of an audit partner's digitalization expertise. To rule out this alternative explanation, we use a fixedeffects model to estimate an average pricing level for each individual audit partner, holding constant the factors unrelated to the partner's individual characteristics. Being consistent with 
our main tests, these results should mitigate such concerns and increase the credibility of our findings. Another limitation regarding virtually all studies on audit fee premia is that, without data on audit hours, we cannot say whether fee premia result from a higher hourly billing rate of experts or whether the experts allocate more audit hours than non-experts. However, despite this limitation, our finding that clients pay higher fees to audit partners who have expertise in client digitalization is novel and extends our current understanding of the dimensions of auditor expertise.

We believe that these results are useful and relevant to those interested in a deeper understanding of the nature of the current auditing environment and auditor expertise - to the clients, to the supervisors of the profession, and to auditors themselves when making decisions on developing their skills and knowledge. Our new measures of audit partner expertise provide an opportunity for further research on the effects of digitalization on auditing. 


\section{Appendix}

TABLE A1

Variable definitions

\begin{tabular}{|c|c|}
\hline Variable & Definition \\
\hline$L N F E E_{i t}$ & The natural logarithm of audit fees paid by client firm $i$ in year $t$. \\
\hline$D I G I \_S P E C 1_{j t}$ & $\begin{array}{l}\text { Audit partner's } j \text { in highly digitalized clients based on the degree of digitalization at the industry level. An indicator } \\
\text { variable that is equal to one if an individual auditor's total audit fees for highly digitalized industries (DIGI_IND>4) } \\
\text { in year } t \text { or } t-1 \text { is higher than the median of all auditors, and zero otherwise. }\end{array}$ \\
\hline$D I G I \_S P E C 2_{j t}$ & $\begin{array}{l}\text { Audit partner's expertise in highly digitalized clients based on industry-level digital strategy clusters. Industries are } \\
\text { grouped into five clusters based on different digitalization strategies (Gandhi et al. 2016) and a group of industries } \\
\text { without any digitalization strategy (comparison group). The five digital strategy clusters are: (1) Knowledge- } \\
\text { intensive, (2) Capital-intensive, (3) Service, (4) Business-to-business (B2B), and (5) Labor-intensive. Highly } \\
\text { localized and fragmented industries, which has the lowest digitalization score, serves as a reference group. An } \\
\text { indicator variable that is equal to one if an individual auditor's total audit fees for any digitalization cluster in year } t \\
\text { or previous year } t-1 \text { is higher than the median of all auditors in that cluster, and zero otherwise. }\end{array}$ \\
\hline$D I G I \_S P E C 3_{j t}$ & $\begin{array}{l}\text { Audit partner's expertise in highly digitalized clients based on their voluntarily reported IT costs. An indicator } \\
\text { variable that is equal to one if an individual auditor's digitalization ratio is higher than the sample median ratio in } \\
\text { year } t \text { or } t-1 \text { and zero otherwise. The digitalization ratio is calculated as the average ratio of the client's IT expenses, } \\
\text { scaled by operating expenses reported voluntarily by client companies ( } 382 \text { firm-years) in year } t \text {. }\end{array}$ \\
\hline$I N D \_S P E C_{j k t}$ & $\begin{array}{l}\text { An indicator variable that is equal to one if an individual auditor's total audit fees for industry } k \text { in year } t \text { are higher } \\
\text { than the median of all auditors in that industry, and zero otherwise. }\end{array}$ \\
\hline$D I G I \_I N D_{k}$ & The level industry digitalization ranging from 0 (low) to 7 (high). \\
\hline PORTFOLIO $_{j t}$ & The natural logarithm of total assets audited by audit partner $j$ in year $t$. \\
\hline$P U B_{j t}$ & The number of listed clients divided by the total number of clients. \\
\hline$L N T A_{i t}$ & The natural logarithm of a client's total assets. \\
\hline$R E C_{i t}$ & Total receivables scaled by total assets. \\
\hline INVREC $C_{i t}$ & The sum of inventories and receivables scaled by total assets. \\
\hline$L_{O S S}$ & An indicator variable that is equal to one if a client reports a negative net income for the period and zero otherwise. \\
\hline$S U B_{i t}$ & The square root of the number of subsidiaries. \\
\hline$S E G_{i t}$ & The square root of the number of segments. \\
\hline
\end{tabular}


TABLE A1 (continued)

\begin{tabular}{ll}
\hline$L I S T E D_{i t}$ & An indicator variable that equals one if the company is publicly listed, and zero otherwise. \\
$I M P_{i j t}$ & Total assets of the client divided by total assets audited by the auditor. \\
$B I G 4_{j t}$ & An indicator variable that is equal to one if the auditor works for Big 4, and zero otherwise. \\
$F E M A L E_{j}$ & An indicator variable that is equal to one if the auditor is female, and zero otherwise. \\
$C H A N G E_{i t}$ & An indicator variable that is equal to one if the audit partner has changed from the previous year, and zero otherwise. \\
$E X P_{j t}$ & Years of auditor experience after taking the CPA exam. \\
\hline
\end{tabular}




\section{References}

Audousset-Coulier, S., A. Jeny, and L. Jiang. 2016. The validity of auditor industry specialization measures. Auditing: A Journal of Practice \& Theory 35(1): 139-161.

Bae, G. S., S. U. Choi, P. T. Lamoreaux, and J. E. Lee. 2020. Auditors' fee premiums and low quality internal controls. Contemporary Accounting Research.

Bauer, T. D., C. Estep, and B. Malsch. 2019. One team or two? Investigating relationship quality between auditors and IT specialists: Implications for audit team identity and the audit process. Contemporary Accounting Research 36(4): 2142-2177.

Bhimani, A., and L. Willcocks. 2014. Digitisation, big data and the transformation of accounting information. Accounting and Business Research 44(4): 469-490.

Bonner, S. E. and B. L. Lewis. 1990. Determinants of auditor expertise. Journal of Accounting Research 28: 1-20.

Brazel, J., and C. Agoglia. 2007. An examination of auditor planning judgements in a complex accounting information system environment. Contemporary Accounting Research 24(4): 1059-1083.

Cahan, S. F., and J. Sun 2015. The effect of audit experience on audit fees and audit quality. Journal of Auditing, Accounting \& Finance 30(1): 78-100.

Chi, H. Y., and C. L. Chin. 2011. Firm versus partner measures of auditor industry expertise and effects on auditor quality. Auditing: A Journal of Practice \& Theory 30(2): 201229.

Cho, S., M. A. Vasarhelyi, and C. A. Zhang. 2019. The forthcoming data ecosystem for business measurement and assurance. Journal of Emerging Technologies in Accounting 16(2): 1-21.

Chow, C. W., J. L. Ho, and S. C. Vera-Munõz. 2008. Exploring the extent and determinants of knowledge sharing in audit engagements. Asia-Pacific Journal of Accounting \& Economics 15(2): 141-160.

DeAngelo, L. E. 1981. Auditor independence, 'low balling', and disclosure regulation. Journal of Accounting and Economics 3(2): 113-127. 
DeFond, M. L., J. R. Francis, and T. J. Wong. 2000. Auditor industry specialization and market segmentation: Evidence from Hong Kong. Auditing: A Journal of Practice \& Theory 19(1): 49-66.

Dowling, C. 2009. Appropriate audit support system use: The influence of auditor, audit team, and firm factors. The Accounting Review 84(3): 771-810.

Edeling, A., and A. Himme. 2018. When does market share matter? New empirical generalizations from a meta-analysis of the market share-performance relationship. Journal of Marketing 82(3): 1-24.

Eierle, B., D. Hay, S. Hartlieb, L. Niemi, H. Ojala. 2019. What drives differences in audit pricing around the world? Working paper. Available at SSRN 3494511

Eilifsen, A., K. Finn, W. F. Messier, Jr., T. McKee, S.B. Anis, and K. Kjellevold. 2019. An exploratory study into the use of audit data analytics on audit engagements. Working paper. Available at SSRN 3458485.

European Commission. 2018. Digital Economy and Society Index (DESI): 2018 Country Report Finland.

Francis, J. R. 1984. The effect of audit firm size on audit prices: A study of the Australian market. Journal of Accounting and Economics 6(2): 133-151.

Francis, J. R. 2004. What do we know about audit quality? The British Accounting Review 36(4): 345-368.

Francis, J. R., M. L. Pinnuck, and O. Watanabe. 2014. Auditor style and financial statement comparability. The Accounting Review 89(2): 605-633.

Gandhi P., S. Khanna, and S. Ramaswamy. 2016. Which industries are the most digital (and why)? Harvard Business Review. https://hbr.org/2016/04/a-chart-that-shows-whichindustries-are-the-most-digital-and-why

Goodwin, J., and D. Wu. 2016. What is the relationship between audit partner busyness and audit quality? Contemporary Accounting Research 33(1): 341-377.

Grabski, S. V., S. A. Leech, and P. J. Schmidt. 2011. A review of ERP research: a future agenda for accounting information systems. Journal of Information Systems 25(1): 3778. 
Gul, F. A., W. Donghui, and Y. Zhifeng. 2013. Do individual auditors affect audit quality? Evidence from archival data. The Accounting Review 88(6): 1993-2023.

Han, S., Z. Rezaee, L. Xue, and J. H. Zhang. 2016. The association between information technology investments and audit risk. Journal of Information Systems 30(1): 93-116.

Hay, D., W. R. Knechel, and N.Wong. 2006. Audit fees: a meta-analysis of the effect of supply and demand attributes. Contemporary Accounting Research 23(1): 141-191.

Hofstede, G. 2011. Dimensionalizing cultures: the Hofstede model in context. Online Readings in Psychology and Culture 2(1).

Hunton, J. E., A. M. Wright, and S. Wright. 2004. Are financial auditors overconfident in their ability to assess risks associated with enterprise resource planning systems?(Retracted). Journal of Information Systems 18(2): 7-28.

Hux, C. T. 2017. Use of specialists on audit engagements: a research synthesis and directions for future research. Journal of Accounting Literature 39: 23-51.

Judge, G., R. C. Hill, W. E. Griffiths, H. L. Utkepohl, and T. C. Lee. 1988. Introduction to the theory and practice of econometrics. New York: Wiley and Sons.

Ittonen, K., and E. Peni. 2012. Auditor's gender and audit fees. International Journal of Auditing 16(1): 1-18.

Kotb, A., and C. Roberts. 2011. The impact of e-business on the audit process: an investigation of the factors leading to change. International Journal of Auditing 15(2): $150-175$.

Krishnan, J. (2005). Audit committee quality and internal control: An empirical analysis. The Accounting Review 80(2): 649-675.

Lemon, W.M., K.W. Tatum, and W.S. Turley. 2000. Developments in the audit methodologies of large accounting firms. London: ABG Professional Information.

Lewis, J. B., and D. A. Linzer. 2005. Estimating regression models in which the dependent variable is based on estimates. Political analysis 13(4): 345-364.

Marquardt, D. W. 1970. Generalized inverses, ridge regression, biased linear estimation, and nonlinear estimation. Technometrics 12(3): 591-256.

McKinsey Global Institute. 2016. Digital Europe: Pushing the frontier, capturing the 
benefits.

Menard, S. 1995. Applied logistic regression analysis: Sage university series on quantitative applications in the social sciences. Thousand Oaks, CA: Sage.

Messier Jr, W. F., A. Eilifsen, and L.A. Austen. 2004. Auditor detected misstatements and the effect of information technology. International Journal of Auditing 8(3): 223-235.

Moizer, P. 1997. Auditor reputation: The international empirical evidence. International Journal of Auditing 1(1): 61-74.

Murthy, U.S., and D.S. Kerr. 2004. Comparing audit team effectiveness via alternative modes of computer-mediated communication. Auditing: A Journal of Practice \& Theory, 23(1): $141-152$.

Niemi, L. 2002. Do firms pay for audit risk? Evidence on risk premiums in audit fees after direct control for audit effort. International Journal of Auditing 6(1): 37-51.

Nwankpa, J., and P. Datta. 2012. Perceived audit quality from ERP implementations. Information Resources Management Journal 25(1): 61-80.

Pathak, J., and M.R. Lind. 2010. An e-business audit service model in the B2B context. Information Systems Management 27(2): 146-155.

Peterson, M.A. 2009. Estimating standard errors in finance panel data sets: comparing approaches. Review of Financial Studies 22(1): 435-480.

Pincus, M., F. Tian, and P. Wellmeyer. 2017. Do clients' enterprise systems affect audit quality and efficiency? Contemporary Accounting Research 34(4): 1975-2021.

Simunic, D.A. 1980. The pricing of audit services: theory and evidence. Journal of Accounting Research 18: 161-190.

Sundgren, S., and T. Svanström. 2014. Auditor-in-charge characteristics and going-concern reporting. Contemporary Accounting Research 31(2): 531-550.

Statistics Finland, 2018a. Use of information technology in enterprises.

Taylor, S.D. 2011. Does audit fee homogeneity exist? premiums and discounts attributable to individual partners. Auditing: A Journal of Practice \& Theory 30(4): 249-272.

Vera-Munõz, S.C., J.L. Ho, and C.W. Chow. 2006. Enhancing knowledge sharing in public accounting firms. Accounting Horizons 20(2): 133-55. 
Zerni, M. 2012. Audit partner specialization and audit fees: some evidence from Sweden. Contemporary Accounting Research 29 (1): 312-340. 
TABLE 1

Industry digitalization levels and digital clusters adapted from the McKinsey Global Institute (2016)

\begin{tabular}{|c|c|c|c|c|c|c|c|c|c|}
\hline \multirow[b]{2}{*}{ Industry } & \multirow[b]{2}{*}{$N$} & \multicolumn{2}{|c|}{ Digitalization } & \multirow{2}{*}{ 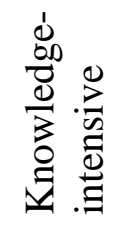 } & \multirow{2}{*}{ 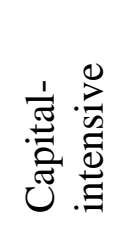 } & \multirow{2}{*}{$\frac{\mathscr{U}}{\sum_{0}^{0}}$} & \multirow{2}{*}{$\stackrel{\oplus}{\sim}$} & \multirow{2}{*}{ 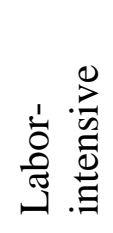 } & \multirow{2}{*}{ 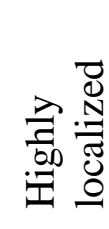 } \\
\hline & & Index & Level & & & & & & \\
\hline ICT & 161 & 7 & High & 1 & 0 & 0 & 0 & 0 & 0 \\
\hline Media & 49 & 7 & High & 1 & 0 & 0 & 0 & 0 & 0 \\
\hline Multiple industry & 57 & 6 & High & 1 & 0 & 0 & 0 & 0 & 0 \\
\hline Professional services & 380 & 5 & High & 1 & 0 & 0 & 0 & 0 & 0 \\
\hline Wholesale trade & 431 & 6 & High & 0 & 1 & 0 & 0 & 0 & 0 \\
\hline Advanced manufacturing & 144 & 5 & High & 0 & 1 & 0 & 0 & 0 & 0 \\
\hline Chemicals and pharmaceuticals & 70 & 4 & Low & 0 & 1 & 0 & 1 & 0 & 0 \\
\hline Utilities & 131 & 4 & Low & 0 & 1 & 0 & 1 & 0 & 0 \\
\hline Basic goods manufacturing & 237 & 3 & Low & 0 & 1 & 0 & 1 & 0 & 0 \\
\hline Mining & 17 & 2 & Low & 0 & 1 & 0 & 1 & 0 & 0 \\
\hline Real estate & 59 & 3 & Low & 0 & 1 & 1 & 1 & 0 & 0 \\
\hline Transportation and warehousing & 90 & 2 & Low & 0 & 0 & 1 & 1 & 0 & 0 \\
\hline Retail trade & 157 & 4 & Low & 0 & 0 & 1 & 0 & 1 & 0 \\
\hline Personal and local services & 80 & 4 & Low & 0 & 0 & 1 & 0 & 1 & 0 \\
\hline Government & 5 & 4 & Low & 0 & 0 & 1 & 0 & 1 & 0 \\
\hline Education & 17 & 3 & Low & 0 & 0 & 1 & 0 & 1 & 0 \\
\hline Entertainment and recreation & 4 & 2 & Low & 0 & 0 & 1 & 0 & 1 & 1 \\
\hline Hospitality & 30 & 2 & Low & 0 & 0 & 1 & 0 & 1 & 1 \\
\hline Agriculture & 12 & 1 & Low & 0 & 0 & 1 & 0 & 1 & 1 \\
\hline Construction & 92 & 0 & Low & 0 & 0 & 1 & 0 & 1 & 1 \\
\hline Total & 2,223 & & & & & & & & \\
\hline
\end{tabular}

Notes: Digital strategies are shown in the final six columns. Financial and insurance service companies are excluded from the sample (NAICS 52). NAICS codes for the industries are as follows: $\mathrm{ICT}=334,5112,517,5182,51913,5415,5170-5179$; Media $=51$ (excluding 5112, 517 , 
5182, 51913); Multiple industry = miscellaneous (includes holding companies operating in more than one industry); Professional services = 56, 8; Wholesale trade $=42$; Advanced manufacturing $=333,335,3361,3364$; Chemicals and pharmaceuticals $=325$; Utilities $=22$; Basic goods manufacturing $=321,327,331,332,337,311,313,315,322,323,324,326$; Mining $=212,213$; Real estate $=53$; Personal and local services $=$ 56, 81; Government $=9 ;$ Education $=61 ;$ Entertainment and recreation $=71 ;$ Hospitality $=72 ;$ Agriculture $=11 ;$ Construction $=23$. 
TABLE 2

Descriptive statistics

\begin{tabular}{lrrrrrrr}
\hline Variable & Mean & Std. & Min & Max & Q1 & Median & \multicolumn{1}{c}{ Q3 } \\
\hline LNFEE & 11.181 & 1.261 & 6.908 & 17.315 & 10.342 & 10.997 & 11.840 \\
DIGI_SPEC1 & 0.545 & 0.498 & 0.000 & 1.000 & 0.000 & 1.000 & 1.000 \\
DIGI_SPEC2 & 0.501 & 0.500 & 0.000 & 1.000 & 0.000 & 1.000 & 1.000 \\
DIGI_SPEC3 & 0.480 & 0.500 & 0.000 & 1.000 & 0.000 & 0.000 & 1.000 \\
IND_SPEC & 0.497 & 0.500 & 0.000 & 1.000 & 0.000 & 0.000 & 1.000 \\
PORTFOLIO & 20.669 & 1.705 & 15.455 & 24.556 & 19.654 & 20.720 & 21.866 \\
PUB & 0.200 & 0.268 & 0.000 & 1.000 & 0.000 & 0.100 & 0.333 \\
DIGI_IND & 4.509 & 1.677 & 0.000 & 7.000 & 3.000 & 5.000 & 6.000 \\
LNTA & 18.806 & 1.426 & 15.416 & 24.528 & 17.742 & 18.601 & 19.619 \\
REC & 0.173 & 0.149 & -0.019 & 0.922 & 0.059 & 0.140 & 0.247 \\
LOSS & 0.219 & 0.414 & 0.000 & 1.000 & 0.000 & 0.000 & 0.000 \\
SUB & 2.274 & 2.769 & 0.000 & 21.679 & 0.000 & 1.732 & 3.606 \\
LISTED & 0.198 & 0.399 & 0.000 & 1.000 & 0.000 & 0.000 & 0.000 \\
IMP & 0.346 & 0.350 & 0.001 & 1.000 & 0.056 & 0.198 & 0.588 \\
BIG4 & 0.919 & 0.272 & 0.000 & 1.000 & 1.000 & 1.000 & 1.000 \\
FEMALE & 0.189 & 0.392 & 0.000 & 1.000 & 0.000 & 0.000 & 0.000 \\
CHANGE & 0.140 & 0.347 & 0.000 & 1.000 & 0.000 & 0.000 & 0.000 \\
EXP & 18.978 & 6.670 & 0.000 & 38.000 & 14.000 & 19.000 & 24.000 \\
\hline
\end{tabular}

Notes: This table presents descriptive statistics of the variables used in the analyses. All variables have 2,223 observations (561 unique clients) except for DIGI_SPEC3, which has 327 observations ( 87 unique firms). $L N F E E=$ natural logarithm of audit fees. DIGI_SPEC1 = indicator variable for audit partner digitalization expertise measured at the industry level. DIGI_SPEC2 = indicator variable for audit partner digitalization expertise based on industrylevel digital strategy clusters. DIGI_IND $=$ level of industry digitalization from 0 (low) to 7 (high). IND_SPEC = indicator variable for audit partner industry specialization. PORTFOLIO = natural logarithm of total assets audited by the audit partner. $L N T A=$ natural logarithm of total assets. $R E C=$ total receivables scaled by total assets. $L O S S=$ indicator variable for negative net income. $S U B=$ square root of the number of subsidiaries. $I M P=$ total assets of the client divided by total assets audited by the auditor. $B I G 4=$ indicator variable for Big 4 auditor. $C H A N G E$ = indicator variable for changed audit partner. Detailed definitions of the variables are provided in the Appendix. 
TABLE 3

Correlations and variance inflation factors

\begin{tabular}{|c|c|c|c|c|c|c|c|c|c|c|c|c|c|c|c|c|c|c|}
\hline & $(1)$ & $(2)$ & (3) & $(4)$ & (5) & (6) & $(7)$ & $(8)$ & (9) & $(10)$ & $(11)$ & $(12)$ & $(13)$ & $(14)$ & $(15)$ & $(16)$ & $(17)$ & (18) \\
\hline (1) LNFEE & 4.07 & 0.20 & 0.48 & 0.12 & 0.57 & 0.45 & 0.50 & 0.04 & 0.61 & 0.05 & 0.11 & 0.61 & 0.50 & 0.02 & 0.22 & 0.00 & 0.01 & -0.01 \\
\hline (2) DIGI_SPECI & 0.18 & 1.34 & 0.25 & 0.29 & 0.22 & 0.36 & 0.24 & -0.01 & 0.13 & 0.03 & 0.00 & 0.04 & 0.10 & -0.34 & 0.24 & 0.12 & 0.08 & -0.05 \\
\hline (3) DIGI_SPEC2 & 0.48 & 0.25 & 1.94 & 0.19 & 0.53 & 0.66 & 0.47 & -0.06 & 0.36 & -0.01 & 0.05 & 0.27 & 0.26 & -0.37 & 0.19 & -0.01 & 0.00 & 0.08 \\
\hline (4) DIGI_SPEC3 & 0.12 & 0.29 & 0.19 & 1.19 & 0.15 & 0.28 & 0.21 & -0.06 & 0.07 & -0.04 & 0.04 & 0.07 & 0.07 & -0.25 & 0.13 & 0.10 & -0.01 & -0.10 \\
\hline (5) IND_SPEC & 0.56 & 0.22 & 0.53 & 0.15 & 1.06 & 0.48 & 0.35 & 0.04 & 0.40 & 0.03 & 0.06 & 0.32 & 0.28 & -0.18 & 0.14 & 0.02 & 0.00 & 0.02 \\
\hline (6) PORTFOLIO & 0.49 & 0.36 & 0.63 & 0.28 & 0.48 & 6.57 & 0.56 & 0.01 & 0.48 & -0.04 & 0.05 & 0.28 & 0.28 & -0.63 & 0.28 & 0.01 & -0.02 & 0.19 \\
\hline (7) $P U B$ & 0.51 & 0.15 & 0.36 & 0.11 & 0.29 & 0.42 & 2.18 & 0.09 & 0.31 & 0.11 & 0.04 & 0.41 & 0.62 & -0.30 & 0.23 & 0.03 & -0.01 & -0.09 \\
\hline (8) DIGI_IND & 0.05 & -0.04 & 0.00 & -0.07 & 0.04 & 0.00 & 0.07 & 1.74 & -0.10 & 0.21 & -0.01 & -0.01 & 0.05 & -0.10 & 0.00 & 0.03 & -0.02 & -0.02 \\
\hline (9) $L N T A$ & 0.70 & 0.11 & 0.38 & 0.08 & 0.40 & 0.54 & 0.35 & -0.06 & 5.41 & -0.37 & -0.04 & 0.44 & 0.28 & 0.27 & 0.07 & -0.03 & 0.05 & 0.09 \\
\hline (10) REC & -0.05 & 0.00 & -0.03 & -0.06 & -0.01 & -0.08 & 0.04 & 0.17 & -0.36 & 1.35 & 0.00 & 0.02 & 0.15 & -0.21 & 0.09 & 0.01 & -0.03 & -0.09 \\
\hline (11) LOSS & 0.08 & 0.00 & 0.05 & 0.04 & 0.06 & 0.06 & 0.01 & -0.01 & -0.04 & -0.01 & 1.07 & 0.02 & 0.01 & -0.10 & 0.09 & -0.01 & -0.03 & -0.07 \\
\hline (12) $S U B$ & 0.70 & 0.01 & 0.29 & 0.05 & 0.33 & 0.34 & 0.44 & 0.00 & 0.57 & -0.06 & 0.00 & 2.39 & 0.56 & 0.10 & -0.01 & -0.11 & 0.03 & 0.03 \\
\hline (13) LISTED & 0.55 & 0.10 & 0.26 & 0.07 & 0.28 & 0.27 & 0.67 & 0.06 & 0.35 & 0.08 & 0.01 & 0.56 & 2.27 & 0.01 & 0.11 & 0.02 & 0.02 & -0.08 \\
\hline (14) IMP & -0.01 & -0.37 & -0.36 & -0.24 & -0.21 & -0.62 & -0.14 & -0.06 & 0.17 & -0.14 & -0.08 & 0.09 & 0.01 & 4.28 & -0.28 & -0.02 & 0.05 & -0.14 \\
\hline (15) BIG4 & 0.20 & 0.24 & 0.19 & 0.13 & 0.14 & 0.29 & 0.16 & -0.02 & 0.09 & 0.02 & 0.09 & 0.03 & 0.11 & -0.31 & 1.22 & 0.11 & -0.01 & -0.06 \\
\hline (16) FEMALE & 0.02 & 0.12 & -0.01 & 0.10 & 0.02 & 0.01 & 0.02 & 0.02 & -0.02 & 0.01 & -0.01 & -0.08 & 0.02 & -0.03 & 0.11 & 1.05 & 0.01 & -0.11 \\
\hline (17) CHANGE & 0.01 & 0.08 & 0.00 & -0.01 & 0.00 & -0.02 & -0.01 & -0.01 & 0.03 & -0.04 & -0.03 & 0.01 & 0.02 & 0.05 & -0.01 & 0.01 & 1.03 & -0.11 \\
\hline (18) EXP & 0.01 & -0.05 & 0.08 & -0.09 & 0.027 & 0.19 & -0.11 & -0.01 & 0.08 & -0.07 & -0.09 & 0.04 & -0.07 & -0.17 & -0.06 & -0.11 & -0.11 & 1.19 \\
\hline
\end{tabular}

Notes: This table presents Pearson (Spearman) correlations below (above) the diagonal. Correlations significant at 0.05 level or better are bolded. Variance Inflation Factors are on the diagonal. All variables have 2,223 observations (561 unique clients) except for DIGI_SPEC3, which has 327 observations ( 87 unique firms). Detailed definitions of the variables are provided in the Appendix. 
TABLE 4

Regression analysis of industry-level digitalization expertise and audit fees

\begin{tabular}{|c|c|c|c|}
\hline & \multicolumn{3}{|c|}{ Dependent variable $=L N F E E$} \\
\hline & (1) & (2) & (3) \\
\hline \multicolumn{4}{|l|}{ Test variables } \\
\hline DIGI_SPECI & & $\begin{array}{l}0.123^{* * * *} \\
(2.71)\end{array}$ & \\
\hline DIGI_SPEC2 & & & $\begin{array}{l}0.298^{* * *} \\
(5.71)\end{array}$ \\
\hline \multicolumn{4}{|c|}{ Portfolio-specific controls } \\
\hline IND_SPEC & $\begin{array}{l}0.648^{* * *} \\
(13.42)\end{array}$ & $\begin{array}{l}0.635^{* * * *} \\
(13.42)\end{array}$ & $\begin{array}{l}0.556^{* * * *} \\
(12.30)\end{array}$ \\
\hline PORTFOLIO & $\begin{array}{l}-0.065^{* *} \\
(-2.16)\end{array}$ & $\begin{array}{l}-0.069 * * \\
(-2.30)\end{array}$ & $\begin{array}{l}-0.109 * * * \\
(-3.45)\end{array}$ \\
\hline$P U B$ & $\begin{array}{l}0.327 \text { *** } \\
(3.49)\end{array}$ & $\begin{array}{l}0.326^{* * *} \\
(3.61)\end{array}$ & $\begin{array}{l}0.282 \text { *** } \\
(3.11)\end{array}$ \\
\hline \multicolumn{4}{|l|}{ Client-specific controls } \\
\hline DIGI_IND & & $\begin{array}{l}0.037 * * \\
(2.02)\end{array}$ & $\begin{array}{l}0.054 * * * \\
(2.94)\end{array}$ \\
\hline LNTA & $\begin{array}{l}0.391 \text { *** } \\
(11.02)\end{array}$ & $\begin{array}{l}0.386^{* * * *} \\
(11.22)\end{array}$ & $\begin{array}{l}0.395^{\text {*** }} \\
(11.41)\end{array}$ \\
\hline$R E C$ & $\begin{array}{l}0.901 \text { *** } \\
(4.79)\end{array}$ & $\begin{array}{l}0.894 * * * \\
(4.76)\end{array}$ & $\begin{array}{l}0.864 * * * \\
(4.65)\end{array}$ \\
\hline LOSS & $\begin{array}{l}0.198^{* * * *} \\
(4.86)\end{array}$ & $\begin{array}{l}0.207 * * * \\
(5.01)\end{array}$ & $\begin{array}{l}0.198^{* * * *} \\
(4.86)\end{array}$ \\
\hline$S U B$ & $\begin{array}{l}0.140^{* * * *} \\
(7.13)\end{array}$ & $\begin{array}{l}0.144 * * * \\
(7.54)\end{array}$ & $\begin{array}{l}0.143^{* * *} * \\
(7.56)\end{array}$ \\
\hline LISTED & $\begin{array}{l}0.187 * * \\
(2.14)\end{array}$ & $\begin{array}{l}0.155^{*} \\
(1.79)\end{array}$ & $\begin{array}{l}0.152^{*} \\
(1.77)\end{array}$ \\
\hline$I M P$ & $\begin{array}{l}-0.215^{*} \\
(-1.81)\end{array}$ & $\begin{array}{c}-0.160 \\
(-1.39)\end{array}$ & $\begin{array}{l}-0.223^{*} \\
(-1.92)\end{array}$ \\
\hline Auditor-specific contr & & & \\
\hline BIG4 & $\begin{array}{l}0.280^{* * * *} \\
(3.04)\end{array}$ & $\begin{array}{l}0.272 \text { *** } \\
(2.93)\end{array}$ & $\begin{array}{l}0.286^{* * * *} \\
(3.07)\end{array}$ \\
\hline FEMALE & $\begin{array}{l}0.088^{*} \\
(1.75)\end{array}$ & $\begin{array}{c}0.080 \\
(1.58)\end{array}$ & $\begin{array}{l}0.098^{* * *} \\
(1.97)\end{array}$ \\
\hline CHANGE & $\begin{array}{c}-0.007 \\
(-0.19)\end{array}$ & $\begin{array}{c}-0.019 \\
(-0.54)\end{array}$ & $\begin{array}{c}-0.002 \\
(-0.05)\end{array}$ \\
\hline EXP & $\begin{array}{c}-0.004 \\
(-1.09)\end{array}$ & $\begin{array}{c}-0.003 \\
(-0.81)\end{array}$ & $\begin{array}{c}-0.003 \\
(-1.03)\end{array}$ \\
\hline Intercept & $\begin{array}{l}4.217 * * * \\
(7.10)\end{array}$ & $\begin{array}{l}4.104 * * * \\
(7.02)\end{array}$ & $\begin{array}{l}4.689 * * * \\
(7.92)\end{array}$ \\
\hline Year fixed effects & Yes & Yes & Yes \\
\hline Industry fixed effects & Yes & Yes & Yes \\
\hline$N$ & 2,223 & 2,223 & 2,223 \\
\hline Adjusted $R^{2}$ & 0.777 & 0.776 & 0.781 \\
\hline
\end{tabular}


Notes: The dependent variable $L N F E E$ = natural logarithm of audit fees. The test variables are DIGI_SPEC1 and DIGI_SPEC2.DIGI_SPEC1 = indicator variable for audit partner digitalization expertise measured at the industry level. DIGI_SPEC2 $=$ indicator variable for audit partner digitalization expertise based on industry-level digital strategy clusters. Detailed definitions of the variables are provided in the Appendix. The $t$-statistics in parentheses are calculated based on White's (1980) heteroscedasticity-consistent standard errors, adjusted for clustering by firm (Peterson 2009). ***,**, and * indicate significance at the $1 \%, 5 \%$, and $10 \%$ levels, respectively (two-tailed). 
TABLE 5

Regression analysis of client-level digitalization expertise and audit fees

\begin{tabular}{|c|c|c|}
\hline & \multicolumn{2}{|c|}{ Dependent variable $=L N F E E$} \\
\hline & (1) & (2) \\
\hline \multicolumn{3}{|l|}{ Test variables } \\
\hline DIGI_SPEC3 & & $\begin{array}{l}0.233 * * \\
(2.12)\end{array}$ \\
\hline \multicolumn{3}{|c|}{ Portfolio-specific controls } \\
\hline IND_SPEC & $\begin{array}{l}0.678^{* * *} \\
(5.42)\end{array}$ & $\begin{array}{l}0.684 * * * \\
(5.53)\end{array}$ \\
\hline PORTFOLIO & $\begin{array}{c}-0.150 \\
(-1.36)\end{array}$ & $\begin{array}{l}-0.162 \\
(-1.48)\end{array}$ \\
\hline$P U B$ & $\begin{array}{l}0.555^{* *} \\
(2.01)\end{array}$ & $\begin{array}{l}0.556^{* *} \\
(2.10)\end{array}$ \\
\hline \multicolumn{3}{|l|}{ Client-specific controls } \\
\hline DIGI_IND & & $\begin{array}{c}0.057 \\
(1.29)\end{array}$ \\
\hline LNTA & $\begin{array}{l}0.408^{* * * *} \\
(3.83)\end{array}$ & $\begin{array}{l}0.426 * * * \\
(4.02)\end{array}$ \\
\hline$R E C$ & $\begin{array}{l}0.683^{*} \\
(1.68)\end{array}$ & $\begin{array}{l}0.830 * * \\
(2.05)\end{array}$ \\
\hline LOSS & $\begin{array}{c}0.137 \\
(1.13)\end{array}$ & $\begin{array}{c}0.146 \\
(1.23)\end{array}$ \\
\hline$S U B$ & $\begin{array}{l}0.174 * * * \\
(4.47)\end{array}$ & $\begin{array}{l}0.166^{* * * *} \\
(4.46)\end{array}$ \\
\hline LISTED & $\begin{array}{r}0.157 \\
(0.70)\end{array}$ & $\begin{array}{c}0.051 \\
(0.25)\end{array}$ \\
\hline$I M P$ & $\begin{array}{c}-0.473 \\
(-1.22)\end{array}$ & $\begin{array}{c}-0.442 \\
(-1.16)\end{array}$ \\
\hline Auditor-specific contr & & \\
\hline BIG4 & $\begin{array}{c}0.246 \\
(1.01)\end{array}$ & $\begin{array}{c}0.239 \\
(0.93)\end{array}$ \\
\hline FEMALE & $\begin{array}{c}0.155 \\
(1.08)\end{array}$ & $\begin{array}{c}0.090 \\
(0.59)\end{array}$ \\
\hline CHANGE & $\begin{array}{c}0.119 \\
(1.30)\end{array}$ & $\begin{array}{l}0.133 \\
(1.45)\end{array}$ \\
\hline EXP & $\begin{array}{r}-0.000 \\
(-0.00)\end{array}$ & $\begin{array}{c}0.001 \\
(0.13)\end{array}$ \\
\hline Intercept & $\begin{array}{l}5.394 * * * \\
(4.14)\end{array}$ & $\begin{array}{l}4.940 * * * \\
(3.82)\end{array}$ \\
\hline Year fixed effects & Yes & Yes \\
\hline Industry fixed effects & Yes & Yes \\
\hline$N$ & 327 & 327 \\
\hline Adjusted $R^{2}$ & 0.762 & 0.770 \\
\hline
\end{tabular}

Notes: The dependent variable $L N F E E$ = natural logarithm of audit fees. The test variable is DIGI_SPEC3 = indicator variable for audit partner digitalization expertise based on the 
clients' voluntarily reported IT costs. Detailed definitions of the variables are provided in Appendix. The $t$-statistics in parentheses are calculated based on White's (1980) heteroscedasticity-consistent standard errors adjusted for clustering by firm (Peterson 2009). $* * *, * *$, and $*$ indicate significance at the $1 \%, 5 \%$, and $10 \%$ levels, respectively (two-tailed). 
TABLE 6

Audit partner fixed effects and digitalization expertise

Panel A: Significance of audit firm and partner fixed effects over the baseline fee model Dependent variable $=$ LNFEE

\begin{tabular}{llll}
\cline { 2 - 4 } & $(1)$ & $(2)$ & $(3)$ \\
\hline Control variables & Yes & Yes & Yes \\
Audit firm fixed effects & No & Yes & Yes \\
Partner fixed effects & No & No & Yes \\
Adjusted $R^{2}$ & 0.718 & 0.736 & 0.795 \\
Increase in adjusted $R^{2}$ & & $0.018^{* * *}$ & $0.059 * * *$ \\
$\mathrm{~N}$ & 2,281 & 2,281 & 2,281 \\
\hline
\end{tabular}

Panel B: The association between audit partner fixed effects and digitalization expertise Dependent variable $=$ Partner fixed effects estimates

(1) (2) (3)

Test variables

DIGI_SPEC1 $0.202 * * *$

DIGI_SPEC2

$0.163 * *$

(2.09)

DIGI_SPEC3

$0.170 * *$

(208)

Auditor-specific controls

$\begin{array}{lccc}\text { IND_SPEC } & 0.424 * * * & 0.400^{* * * *} & 0.460^{* * * *} \\ \text { FEMALE } & (6.08) & (5.21) & (6.24) \\ \text { EXP } & 0.127 & 0.165 & 0.157 \\ & (1.10) & (1.44) & (1.37) \\ \text { Intercept } & 0.009 & 0.009 & 0.009 \\ & (1.40) & (1.46) & (1.50) \\ N & -0.370^{*} & -0.410^{* *} & -0.410^{* *} \\ N \text { of unique partners } & (-1.86) & (-2.01) & (-1.99) \\ \text { Adjusted } R^{2} & 809 & 809 & 809 \\ & 232 & 232 & 232 \\ \end{array}$

Notes: Column 1 of panel A reports the adjusted R-square of the baseline fee model (1): LNFEE $_{i t}=\beta_{0}+\beta_{1}$ PORTFOLIO $_{j t}+\beta_{2}$ PUB $_{j t}+\beta_{3}$ LNTA $_{i t}+\beta_{4}$ REC $_{i t}+\beta_{5}$ LOSS $_{i t}+\beta_{6} S U B_{i t}+\beta_{7}$ LISTED $_{i t}+\beta_{8} I M P_{i j t}+\beta_{9} B I G 4_{j t}+\beta_{10} C H A N G E_{i t}+$ year fixed effects + industry fixed effects + $\varepsilon_{i t}$. Detailed definitions of the variables are provided in the Appendix. In column 2, audit firm fixed effects for 30 unique audit firms are added to the baseline fee model (1). In column 3 , partner fixed effects for 232 unique partners are added to the audit firm fixed effects model (2). Panel B reports the results from OLS regressions where the dependent variable is the vector of estimated auditor fixed effects (Gul et al. 2013). The coefficients of audit partner fixed effects lacking statistical significance (p. > 0.05) were adjusted to zero. The results regarding tabulated variables are not sensitive to this adjustment. The $t$-statistics in parentheses are calculated based on White's (1980) heteroscedasticity-consistent standard 
errors adjusted for additional sampling error due to having a set of estimated parameters as the dependent variable (Lewis and Linzer 2005) and clustering by firm (Peterson 2009). ***, $* *$, and $*$ indicate significance at the $1 \%, 5 \%$, and $10 \%$ levels, respectively (one-tailed in panel A, two-tailed in panel B). 
TABLE 7

Descriptive statistics for the U.S. sample

\begin{tabular}{lrrrrrrr}
\hline Variable & Mean & Std. & Min & Max & Q1 & Median & Q3 \\
\hline LNFEE & 13.587 & 1.628 & 7.601 & 18.378 & 12.486 & 13.771 & 14.716 \\
DIGI_SPEC1 & 0.461 & 0.499 & 0.000 & 1.000 & 0.000 & 0.000 & 1.000 \\
DIGI_SPEC2 & 0.493 & 0.500 & 0.000 & 1.000 & 0.000 & 0.000 & 1.000 \\
IND_SPEC & 0.299 & 0.458 & 0.000 & 1.000 & 0.000 & 0.000 & 1.000 \\
PORTFOLIO & 21.088 & 2.520 & 6.382 & 27.512 & 19.495 & 21.247 & 22.887 \\
DIGI_IND & 4.917 & 1.240 & 2.000 & 7.000 & 5.000 & 5.000 & 5.000 \\
LNTA & 19.762 & 3.036 & 6.368 & 27.000 & 17.943 & 20.055 & 21.844 \\
INVREC & 0.191 & 0.189 & 0.000 & 1.000 & 0.042 & 0.136 & 0.288 \\
LOSS & 0.486 & 0.500 & 0.000 & 1.000 & 0.000 & 0.000 & 1.000 \\
SEG & 2.611 & 1.240 & 1.000 & 12.329 & 1.732 & 2.449 & 3.464 \\
IMP & 0.506 & 0.377 & 0.000 & 1.000 & 0.143 & 0.466 & 1.000 \\
BIG4 & 0.650 & 0.477 & 0.000 & 1.000 & 0.000 & 1.000 & 1.000 \\
CHANGE & 0.090 & 0.287 & 0.000 & 1.000 & 0.000 & 0.000 & 0.000 \\
\hline
\end{tabular}

Notes: This table presents descriptive statistics for the U.S. dataset, obtained from Audit Analytics and Compustat. All variables have 12,185 observations (4,486 unique clients). Detailed definitions of the variables are provided in the Appendix. 
TABLE 8

Regression analysis of digitalization expertise and audit fees with the U.S. sample

\begin{tabular}{|c|c|c|c|}
\hline & \multicolumn{3}{|c|}{ Dependent variable $=L N F E E$} \\
\hline & (1) & (2) & (3) \\
\hline \multicolumn{4}{|l|}{ Test variables } \\
\hline DIGI_SPECl & & $\begin{array}{l}0.501 * * * \\
(22.35)\end{array}$ & \\
\hline DIGI_SPEC2 & & & $\begin{array}{l}0.491 \text { *** } \\
(21.51)\end{array}$ \\
\hline \multicolumn{4}{|c|}{ Portfolio-specific controls } \\
\hline IND_SPEC & $\begin{array}{l}0.463 * * * \\
(17.02)\end{array}$ & $\begin{array}{l}0.432 * * * \\
(16.75)\end{array}$ & $\begin{array}{l}0.448 * * * \\
(16.98)\end{array}$ \\
\hline PORTFOLIO & $\begin{array}{l}0.119 * * \\
(10.37)\end{array}$ & $\begin{array}{l}0.091 * * * \\
(8.30)\end{array}$ & $\begin{array}{l}0.090 * * * \\
(8.14)\end{array}$ \\
\hline \multicolumn{4}{|l|}{ Client-specific controls } \\
\hline DIGI_IND & & $\begin{array}{l}0.016 \\
(1.33)\end{array}$ & $\begin{array}{l}0.092 * * * \\
(7.47)\end{array}$ \\
\hline LNTA & $\begin{array}{l}0.276 \text { *** } \\
(25.71)\end{array}$ & $\begin{array}{l}0.263^{* * * *} \\
(25.31)\end{array}$ & $\begin{array}{l}0.262 * * * \\
(25.27)\end{array}$ \\
\hline INVREC & $\begin{array}{l}0.317 * * * \\
(5.18)\end{array}$ & $\begin{array}{l}0.316^{* * * *} \\
(5.44)\end{array}$ & $\begin{array}{l}0.322 * * * \\
(5.57)\end{array}$ \\
\hline LOSS & $\begin{array}{l}0.174 * * * \\
(8.75)\end{array}$ & $\begin{array}{l}0.160 \text { *** } \\
(8.54)\end{array}$ & $\begin{array}{l}0.166^{* * * *} \\
(8.68)\end{array}$ \\
\hline SEG & $\begin{array}{l}0.136 * * * \\
(12.80)\end{array}$ & $\begin{array}{l}0.122^{* * * *} \\
(12.69)\end{array}$ & $\begin{array}{l}0.113^{* * * *} \\
(11.49)\end{array}$ \\
\hline$I M P$ & $\begin{array}{l}0.499 * * * \\
(13.00)\end{array}$ & $\begin{array}{c}0.601 \\
(16.26)\end{array}$ & $\begin{array}{l}0.554 * * * \\
(14.94)\end{array}$ \\
\hline Auditor-specific contr & & & \\
\hline$B I G 4$ & $\begin{array}{l}0.496 * * * \\
(17.73)\end{array}$ & $\begin{array}{l}0.377 * * * \\
(14.62)\end{array}$ & $\begin{array}{l}0.403^{* * * *} \\
(15.19)\end{array}$ \\
\hline CHANGE & $\begin{array}{l}-0.297 * * * \\
(-9.68)\end{array}$ & $\begin{array}{l}-0.291 * * * \\
(-9.87)\end{array}$ & $\begin{array}{l}-0.311^{* * *} \\
(-10.48)\end{array}$ \\
\hline Intercept & $\begin{array}{l}3.784 * * * \\
(18.82)\end{array}$ & $\begin{array}{l}4.429 * * * \\
(22.70)\end{array}$ & $\begin{array}{l}4.076 \text { *** } \\
(21.37)\end{array}$ \\
\hline Year fixed effects & Yes & Yes & Yes \\
\hline Industry fixed effects & Yes & Yes & Yes \\
\hline$N$ & 12,185 & 12,185 & 12,185 \\
\hline Adjusted $R^{2}$ & 0.832 & 0.845 & 0.844 \\
\hline
\end{tabular}

Notes: Detailed definitions of the variables are provided in the Appendix. The $t$-statistics in parentheses are calculated based on White's (1980) heteroscedasticity-consistent standard errors adjusted for clustering by firm (Peterson 2009). ***, **, and * indicate significance at the $1 \%, 5 \%$, and $10 \%$ levels, respectively (two-tailed). 